curriculum on which the government has properly set its heart) is that good sense will be undermined by the government's equal fondness for arrangements under which schools will be able to opt for independence from the local authorities that now control them, often no doubt to pursue selective educational policies of their own.

That will be contentious enough, but will be doubly so if the attainment tests now being designed are used not merely as determinants of students schooling (which is proper), but as ways of telling which schools they physically attend. That is why the government should be required to declare, in advance of the consultations on which its new array of curriculum councils is embarking, that it intends to make the national curriculum what the name implies. The curriculum, as modified in the light of changing circumstances, will realistically be a sign of what school-leavers have studied and have been helped to understand. If a student's attainment on some test is unsatisfactory, he or she will be helped to acquire the missing understanding. Attainment tests must therefore be educationally diagnostic, not instruments of educational apartheid. Without that undertaking, the national curriculum will be meaningless.

But how can such an undertaking be given when the resources available to the schools are as meagre as at present? Teachers complain at the lack of funds, but the more serious shortage is of people. Gifted mathematics teachers are too few to satisfy the needs of the modest curriculum proposed by last week's mathematics panel. Although the theme of the science panel is that science and technology should properly be a part of general education, it is nowhere demonstrated that instruction can be safely left in the hands of generalists. Yet that will be the result if, in the British educational system as a whole, the decline of interest in science courses in higher education continues at the alarming pace of the past few years. Despite recent contractions of capacity, British universities in particular are increasingly hard-pressed to fill the available science places with enthusiastic occupants. In short, there is a danger that the success of the best part of the Educational Reform Act will be vitiated by the separate provisions that have blighted higher education.

\section{Prospect for US sciences}

\section{Which two US parties' policies on science will} best control the deficit?

THERE was nothing in last week's convention of the Republican Party at New Orleans overtly intended to win votes at the election on 8 November, and very little at the earlier Democratic convention at Atlanta. Mr Michael Dukakis had a few uplifting things to say about the need to restore respect and self-respect to teachers as a whole and about the need to make full use of the inventiveness of laboratory people, but none of that can be counted as vote-catching. Left to themselves, both parties would probably follow the present administration in seeking to back the US research enterprise to the hilt, but with a few important differences (see p.639). What stands out from the conventions so far is that neither party has yet paid much public attention to the ways in which the post-election policies of the United States will be determined by considerations beyond the control of whatever party's champion is elected.

The unspoken questions so far are financial, and centre on the two still-huge deficits with which the United States is lumbered. The federal budget deficit (roughly $\$ 150,000$ million this year) is a measure of the degree to which the administration cannot pay its own bills from its revenue and is forced to meet the gap by borrowing instead; the external deficit, now fluctuating from month to month in the wake of the dollar devaluation but back to more than $\$ 12,000$ million last month, is a measure of the degree to which the borrowings are made from lenders overseas.

In principle, as the present administration has been fond of saying, there is no reason why the two deficits should not persist. The precondition is merely that borrowers should be prepared to keep on lending until the US economy (and, with it, the yield of statutory taxes) grows to the point at which the federal deficit is once more in balance. The cost, of course, has been considerable. The United States is now the largest debtor nation (by a factor of three) while the devaluation of the dollar in the past nine months has made it easier for people overseas to buy US industrial enterprises at knock-down prices. But will foreigners keep lending to keep the US administration afloat? It has always been on the cards that their mood would change with the administration, somewhere between 8 November and midJanuary next year; this likelihood has been increased by the increased interest rates now to be had elsewhere.

Even the past year's experience should make it plain that the changing economic pattern can seriously affect the federal government's capacity to support basic science. Once again, for example, the administration's laudable goal of doubling the budget of the National Science Foundation has been attenuated by the congressional agreement that the budget would be kept within limits derived from the old Gramm-Rudman rules (but less rigorous than those originally prescribed). Like it or not, science spending is discretionary spending, and must share with, for example, the military budget whatever cash is left over after statutory obligations (social security and the like) have been met. To judge from what the two presidential candidates have been saying, Dukakis will have the greater freedom to manoeuvre for the benefit of science: he believes that military spending could be reduced, while Mr George Bush has tied one hand behind his back by promising not to increase taxes. But it is too soon to know what will happen when one candidate or the other confronts reality.

That is why there is now an urgent need for some kind of contingency plan that will at once allow the federal deficit to be reduced to something like zero over a well-defined period (too sharp a reduction would be deflationary, and is in any case not required by lenders overseas) and which will allow some slack in the system for supporting basic science and its application, the need for which is crucial to the continuing renewal of the US economy. The difficulty, in the United States, is that some spending apparently peripheral to economic causes, including both military spending and the Strategic Defense Initiative, is far from irrelevant to the civilian economy. Companies commissioned one year to devise a customized chip for some esoteric spacecraft may, the next, find themselves incorporating the same device in some well-selling item aimed at consumers. But it is an assault on logic to suppose that practical benefits obtained as by-products of military projects are more economically won than those that derive from well-directed programmes of research. The presumption must be that the United States will gain more more cheaply from the support of innovatory research groups than from its extravagant ventures into future military and space technology.

This does not beg the strategic question, certain to dominate the next two months, of whether US military strength is a prerequisite of an accommodation with the Soviet Union on strategic arms control. It is merely that the change of an administration (not necessarily a change of party) provides an opportunity for disowning past commitments. Thus, it is even possible that Bush, if elected in November, could reasonably decide that there is no great need to hurry with the planned space stations and that the Strategic Defense Initiative would profit from being allowed to mature in the minds of its creators a little longer. Cutting loose from a few ventures of that kind for the sake of being able to spend a fraction of the funds (say a quarter) on basic science would be a good bargain, domestically and perhaps internationally as well. For whatever the election brings, the next administration will be the first in the United States that will have to learn that counting pennies is not merely a virtue but a necessity. 